\title{
Potensi Pariwisata di Desa Katurei Kecamatan Siberut Barat Daya Kabupaten Kepulauan Mentawai
}

\author{
Ni Luh Anggela \\ Program Studi Ilmu Komunikasi, \\ Universitas Katolik Soegijapranata \\ Peter Ardhianto \\ Program Studi Desain Komunikasi Visual \\ UniversitasKatolik Soegijapranata
}

\begin{abstract}
Abstrak: Penelitian ini mengkaji tentang Potensi Pariwisata di Desa Katurei Kecamatan Siberut Barat Daya Kabupaten Kepulauan Mentawai. Oleh karena itu, berkaitan dengan pengembangan pariwisata yang terjadi di Desa Katurei, studi ini mendeskripsikan hal-hal yang menjelaskan tentang apa saja potensi wisata di Desa Katurei. Penelitian ini menggunakan metode deskriptif dengan data kualitatif. Data diperoleh dari studi pustaka, observasi, wawancara, dan dokumentasi. Data dari hasil yang diperoleh menjelaskan bahwa Desa Katurei memiliki potensi sebagai desa wisata. Sayangnya kurang adanya pergerakan dari BUMDes membuat desa Katurei belum dapat mengembangkan potensi wisatanya sehingga diharapkan adanya kegiatan pendampingan bagi anggota BUMDes. Desa Wisata diharapkan dapat membantu permasalahan perekonomian yang ada di desa Katurei.
\end{abstract}

\section{Keyword: Potensi, Pariwisata, Mentawai}

\section{PENDAHULUAN}

Pariwisata menjadi salah satu cara yang paling diminati oleh suatu negara dalam meningkatkan sumber pendapatannya, baik pendapatan negara maupun daerah wisata tujuan. Pembangunan pariwisata diharapkan dapat memberikan dampak positif bagi masyarakat seperti menciptakan lapangan kerja baru hingga meningkatkan kualitas hidup masyarakat. Dalam UU nomor 10 tahun 2009 pasal 1 ayat 3 disebutkan bahwa Pariwisata adalah berbagai macam kegiatan wisata dan didukung berbagai fasilitas serta layanan yang disediakan oleh masyarakat, pengusaha, pemerintah dan pemerintah daerah.

Potensi sumber daya alam dan sumber daya manusia di daerah pedesaan cukup besar. Masyarakat di Indonesia sebagian besar tinggal di pedesaan, oleh karena itu pembangunan yang berfokus pada pedesaan 
merupakan suatu tindakan yang sangat efektif karena baik secara langsung maupun tidak langsung dapat memberikan dampak yang positif.

Desa wisata merupakan suatu bentuk integrasi antara atraksi, akomodasi, dan fasilitas pendukung yang disajikan dalam suatu struktur kehidupan masyarakat yang menyatu dengan tata cara dan tradisi yang berlaku. Keaslian dan keunikan dari berbagai atraksi produk yang ditampilkan menjadi daya tarik suatu desa wisata.

Adanya pergeseran minat wisatawan dari keindahan alam dan lengkapnya fasilitas membuat masyarakat pedesaan perlu memiliki kesiapan dalam menjadikan desanya sebagai tempat wisata. Desa yang memiliki ciri khas baik alam maupun budaya yang sesuai dengan tuntutan wisatawan di masa sekarang dimana mereka dapat menikmati, mengenal, dan mempelajari keunikan desa.

Desa Katurei merupakan salah satu desa yang berada di pulau Siberut kecamatan Siberut Barat Daya, kabupaten Kepulauan Mentawai, Sumatera Barat. Desa Katurei terdiri dari dusun Tiop, dusun Matobat, dusun Atateitei, dusun Sarasau, dusun Makakaddut, dusun Malilimok, dusun Mapailingen dan dusun Tolou Loggo.

Penduduk di desa Katurei sebagian besar berasal dari suku Mentawai.
Masyarakat sehari-hari menggunakan bahasa Mentawai dan bahasa Indonesia sebagai bahasa kedua mereka. Rumahrumah warga sebagian besar masih rumah panggung yang terbuat dari papan dan daun sagu sebagai atap.

Desa Katurei merupakan daerah yang memiliki potensi yang bagus sebagai salah satu tujuan wisatawan dalam melakukan kegiatan wisata. Wisata alam dan budaya menjadi daya tarik wisatawan untuk melakukan kegiatan maupun perjalanan wisata yang ada di desa Katurei.

Sayangnya hingga saat ini, desa Katurei belum dapat mewujudkan desa mereka sebagai daerah wisata. Berangkat dari fakta tersebut, penulis tertarik untuk meneliti potensi pariwisata di desa Katurei.

\section{RUMUSAN MASALAH}

Apa saja potensi wisata di desa Katurei?

\section{METODE}

Dalam penelitian ini, metode yang digunakan ialah kualitatif dengan pendekatan deskriptif. Adapun penelitian ini dilaksanakan di Desa Katurei kecamatan Siberut Barat Daya. Penelitian dilakukan pada tanggal 8-28 Januari 2019. Penelitian ini menggunakan teknik observasi dan wawancara bersama masyarakat di desa Katurei.

Sumber data yang digunakan adalah 
data primer dan sekunder. Data primer merupakan data yang diperoleh langsung di lapangan melalui objek yang diteliti. Sedangkan data sekunder adalah data yang melengkapi data primer, yang diperoleh dari buku, berita, studi terdahulu dan internet.

Teknik pengumpulan data yang digunakan yakni:

a. Studi Pustaka

Studi dokumen dilakukan dengan memahami berbagai sumber tertulis, media digital dan media cetak seperti hasil penelitian yang berkaitan.

b. Observasi

Observasi dilakukan di desa Katurei kecamatan Siberut Barat Daya, kabupaten Kepulauan Mentawai.

c. Wawancara

Wawancara dilakukan dengan orangorang yang memiliki pengetahuan luas mengenai pariwisata di desa Katurei, seperti kepala desa, BUMDes, kepala dusun serta informan lain yang diperkirakan dapat mem-perbanyak data penelitian ini.

d. Dokumentasi

Dokumentasi yang digunakan berupa foto-foto yang diambil untuk kepentingan dokumentasi berupa foto kegiatan desa Katurei serta gambar lain yang dianggap penting untuk penelitian ini.

\section{HASIL PEMBAHASAN}

\section{Potensi Desa Wisata Desa Katurei}

\section{Atraksi Alam}

a. Perkebunan

Masyarakat di desa Katurei memiliki ladang yang letaknya jauh dari tempat tinggal mereka, bahkan berada di pulau yang berbeda. Ladang mereka biasanya ditanami pohon durian, pisang, mangga dan lain-lain. Walaupun ketika dipanen keuntungan yang diperoleh dari penjualan tergolong cukup rendah, minat masyarakat tidak surut untuk terus berkebun. Biasanya masyarakat akan menghabiskan berminggu-minggu di kebun. Beberapa atraksi wisata perkebunan yang dapat dilakukan antara lain sebagai berikut.

a) Menanam bibit buah-buahan

Wisatawan akan diberi pengetahuan dan wawasan mengenai proses penanaman buah-buahan seperti durian, pisang, mangga dan sebagainya. Wisatawan yang berkunjung turut serta mempraktikan proses penanaman buah-buahan ini.

b) Memanen hasil kebun Wisatawan dapat melihat dan mempelajari proses memanen hasil kebun. Wisatawan juga 
akan diarahkan bagaimana cara memetik dan memilih buah yang siap panen. Selanjutnya wisatawan yang ingin membeli dapat langsung memetiknya sendiri.

c) Mengolah durian menjadi dodol

Pada KKN APM sebelumnya, masyarakat setempat sudah dibekali cara membuat dodol dari durian. Wisatawan akan diajarkan proses pembuatan dodol hingga pengemasannya. Selanjutnya wisatawan juga dapat membawa dodol yang telah dibuat setelah membayarnya terlebih dahulu.

b. Membuat dodol dan sirup kojo

Di desa Katurei, banyak dijumpai tanaman kojo. Kegiatan ini bisa menjadi salah satu kegiatan wisata yang menarik karena kojo ini sangat jarang ditemui. Pada KKN APM 4, masyarakat sudah diajarkan dan dibekali cara membuat dodol dan sirup kojo, hingga pada pengemasannnya. Wisatawan akan diajak untuk memetik kojo dan cara memilih kojo yang telah matang. Kemudian wisatawan akan diajarkan cara membuat dodol dan sirup kojo hingga cara mengemasnya.

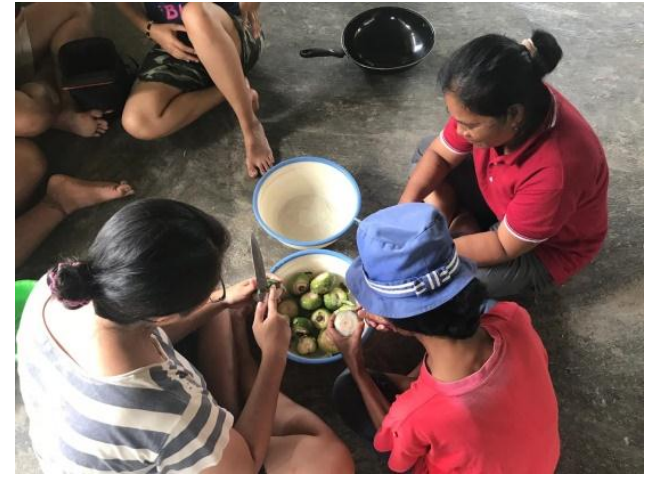

Gambar 1. Proses pembuatan sirup dan dodol kojo. (Sumber: Dok. Pribadi)

c. Membuat abon ikan

Desa Katurei memiliki kekayaan alam yang melimpah. Salah satunya yakni kekayaan lautnya. Pada KKN APM 2 dan 4, masyarakat sudah dibekali cara mengolah ikan menjadi abon. Wisatwan akan diajarkan cara mengolah ikan menjadi abon ikan. Wisatawan yang ingin membeli, bisa membelinya dengan kisaran harga $\mathrm{Rp} 20.000,00$ $-30.000,00 /$ bungkus.

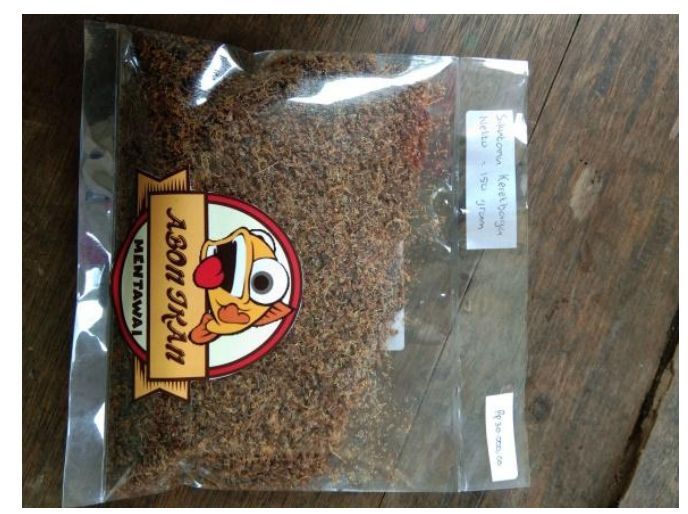

Gambar 2. Abon ikan yang sudah dikemas. (Sumber: Dok. Pribadi) 
d. Menjaring ikan

Sebagian besar ibu-ibu di Desa Katurei setiap hari pergi menjaring ikan di laut menggunakan alat-alat tradisional. Ini menarik untuk dijadikan kegiatan wisata karena kegiatan ini jarang dijumpai di daerah perkotaan. Kemudian untuk pergi menjaring, ibu-ibu di desa Katurei menggunakan sampan dan mendayungnya sendirian. Wisatawan akan diajak dan diajarkan bagaimana mendayung sampan dan menjaring ikan di laut.

e. Meracik tanaman obat

Sebagian besar masyarakat di sana masih mengandalkan pengobatan secara tradisional dengan memanfaatkan tanaman obat. Wisatawan akan diajak untuk mencari tanaman obat yang diperlukan serta diajarkan bagaimana cara meraciknya.

\section{Atraksi Budaya}

a. Upacara adat

Masyarakat di daerah Mentawai khususnya di desa Katurei masih sangat kental dengan adat istiadatnya. Salah satu upacara yang menarik untuk diikuti adalah upacara kematian. Dalam upacara ini, wisatawan bisa menyaksikan proses upacara kematian di daerah
Mentawai dan bisa turut serta dalam prosesi tersebut.

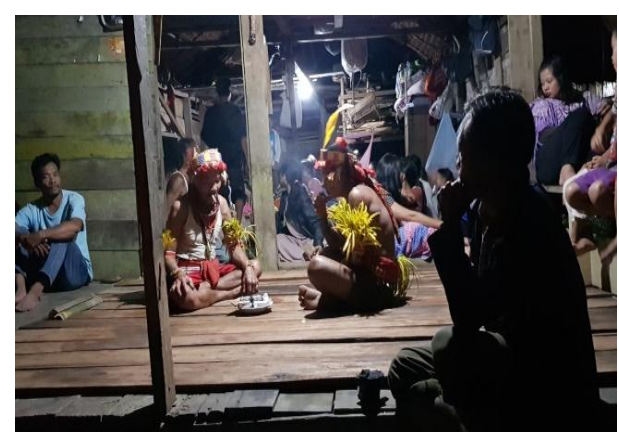

Gambar 3. Salah satu rangkaian upacara kematian. (Sumber: Dok. Pribadi)

b. Membuat perhiasan khas Mentawai Selama tinggal beberapa minggu di sana, bisa dilihat bahwa masyarakat sangat pandai dalam membuat perhiasan seperti, kalung dan gelang dari manik-manik khas Mentawai, gelang dan cincin dari rotan, serta perhiasan dari kulit penyu. Kegiatan ini menjadi daya tarik sendiri bagi wisatawan. Wisatawan juga dapat belajar bagaimana membuat perhiasan dari bahan-bahan tadi. Harganya pun bervariasi jika ada wisatawan yang ingin membelinya.

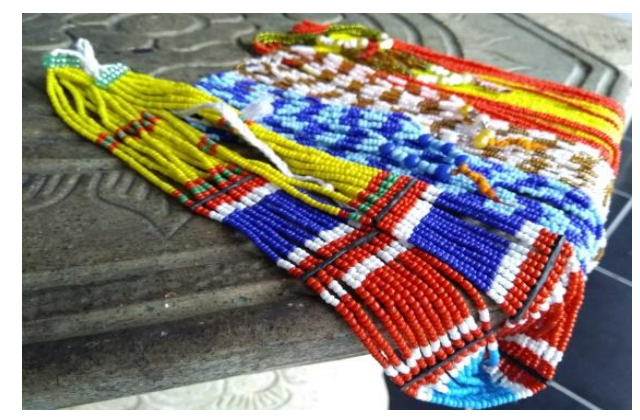

Gambar 4. Perhiasan khas Mentawai. (Sumber: Dok. Pribadi) 
c. Tarian tradisional budaya Mentawai (Muturuk Laggai)

Mahasiswa KKN APM selalu diajarkan tarian-tarian tradisional yang ada di Mentawai yang kemudian ditampilkan di saat acara perpisahan. Ini bisa menjadi daya tarik wisatawan, karena untuk belajar tarian Mentawai tergolong cukup mudah. Nantinya tarian yang telah dipelajari ini akan dipertunjukan di Balai Dusun bersama masyarakat lainnya dengan mengenakan busana adat Mentawai.

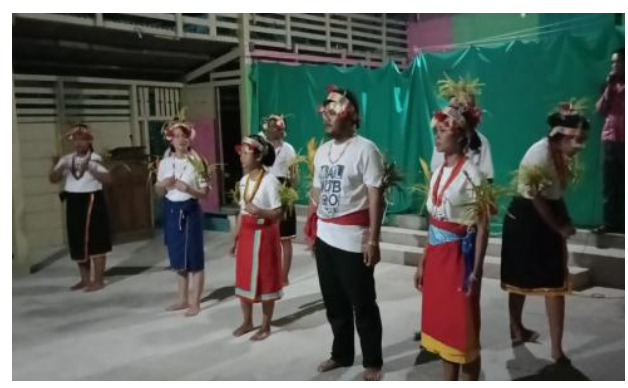

Gambar 5. Pementasan tarian tradisional oleh mahasiswa KKN. (Sumber: Dok. Pribadi)

d. Panahan tradisional Mentawai

Berdasarkan penelusuran penulis, panahan tradisional ini baru diadakan di kecamatan Siberut Selatan. Padahal hampir seluruh kepala keluarga di desa Katurei memiliki panah. Kegiatan ini bisa dijadikan perlombaan, sehingga dapat menarik minat wisatawan.
Wisatawan juga dapat ambil bagian dalam lomba panahan ini.

\section{KESIMPULAN}

Desa Katurei merupakan salah satu tempat yang berpotensi menjadi desa wisata. Ini dapat dilihat dari kekayaan alam dan atraksi budaya yang telah dijabarkan sebelumnya. Masyarakat disana sudah cukup mampu untuk melakukan kegiatankegiatan yang ada (yang telah diajarkan oleh mahasiswa KKN) dan mempertahankan kebudayaan yang mereka miliki. Sayangnya, BUMDes yang ada di desa Katureibelum dapat mengoptimalkan kinerjadan peluang yang ada untuk meningkatkan perekonomian di desa Katurei. Oleh karena itu, sangat perlu untuk mengadakan kegiatan pendampingan bagi anggota BUMDes agar dapat menjalankan tugas sebagaimana mestinya. Karena dari pandangan penulis, masyarakat sendiri sudah cukup siap untuk melaksanakan beberapa kegiatan yang telah dijabarkan sebelumnya dan banyaknya potensi wisata di Desa Katurei. 


\section{UCAPAN TERIMA KASIH}

Ucapan terimakasih tak terhingga kepada APTIK (Asosiasi Perguruan Tinggi Katolik) dengan program APTIK Peduli Mentawai yang membawa para penulis ke

Mentawai. Serta LPPM Unika Soegijapranata atas kesempatan yang diberikan pada penulis. Ketua BUMDes Sdr. Klian di Dusun Malilimok Katurei, peserta serta Dosen Pembimbing Lapangan dari berbagai kampus katolik di Indonesia yang turut serta mengabdi di Mentawai.

\section{DAFTAR PUSTAKA}

Purnamasari,Andi Maya.

(2011).Pengembangan Masyarakat untuk Pariwisata di Kampung Wisata Toddabojo Provinsi Sulawesi Selatan. Jurnal Perencanaan Wilayah dan Kota. Vol 22: hal 54

Razak, Abdur., \&Rimadewi

Suprihardjo.(2013). Pengembangan

Kawasan Pariwisata Terpadu di Kepulauan Seribu. Jurnal Teknik POMITS. Vol 2: hal 2.

Saputra, Fiqri Syahwidi. (2018).Potensi

Pariwisata Dalam Pemberdayaan

Masyarakat Di Pulau Belimbing

Kecamatan Kuok Kabupaten

Kampar.Jom Fisip. Vol 5: Hal 5-8

Yayasan Pendidikan Budaya Mentawai.

(2018). Festival Pertunjukan Budaya

Mentawai. Retrieved from

http://www/sukumentawai.org/id/2018/

09/festival-pertunjukan-budaya-

mentawai/ 